Islands Expedition, 6 Woodland Court, Woodlands, London, N.W.11.

\section{Meres Senior Studentship for Medical Research, 1965}

The Council of St. John's College, Cambridge, is offering a Meres senior studentship for medical research. A candidate must be a graduate of a university, and may be of either sex. It is not a condition of election that he shall have been admitted to a degree in medicine or surgery. The student will be elected for a period of not less than one year or more than three years, as from a date not earlier than Oetober 1, 1965, or later than April 1, 1966, to be approved by the Council. The student will be required to devote himself to medical research in any field approved by the Council. The research must be pursued in the University of Cambridge or in some place in the neighbourhood of Cambridge approved by the Council. The emolument of the studentship will be between $£ 1,500$ and $£ 3,000$ per annum depending on qualifications, seniority, and other circumstances of the applicant. The studentship is not, without the consent of the Council, tenable with a fellowship of any college or with any other studentship, scholarship or emolument, or with a salaried post; nor will the holder, without the consent of the Council, be permitted to undertake paid work, engage in private professional practice, or be a candidate for examinations for diplomas or professional qualifications. Applications must be sent, not later than November 1 , to the Master, St. John's College, Cambridge, from whom further details of the studentship and the method of application can be obtained.

\section{The Night Sky in July}

New moon occurs on July 9d $11 \mathrm{~h}$ 3Im U.T. and full moon on July $24 \mathrm{~d} 15 \mathrm{~h} 58 \mathrm{~m}$. The following conjunctions with the Moon occur: July 5d 12h, Jupiter $3^{\circ}$ N.; July 7d 06h, Mars $2^{\circ}$ N.; July 27d 03h, Saturn $3^{\circ}$ N. Mars is in conjunction with Aldebaran on July ld 18h, Mars beirg $6^{\circ}$ N., Mercury with Pollux on July $5 \mathrm{~d} 18 \mathrm{~h}$. Mereury boir $5^{\circ} \mathrm{S}$. , Verus with Mars on July $18 \mathrm{~d} 07 \mathrm{~h}$, Venus beirig $5^{\circ} \mathrm{S}$., and Mercury with Regulus on July $27 \mathrm{~d} 02 \mathrm{~h}$, Mercury beir $g .3^{\circ} \mathrm{S}$. There is a partial eclipse of the Sun on July 9, invisible at Greenwich. Mercury is too close to the sun for observation. Venus is \& morning star, rising at $3 \mathrm{~h} 00 \mathrm{~m}, 2 \mathrm{~h} 10 \mathrm{~m}$ and $1 \mathrm{~h} 30 \mathrm{~m}$ on July 1,15 and 31 , respectively. Its stellar magnitudo is $-4 \cdot 1$; greatest brilliancy is attained on July 26 . It.s distance from the Earth increases during the month from 29 to 46 million miles and the visible portion of the apparent disk from 0.045 to 0.320 . Mars rises three hours before the Sun on July 3I, and is visible low in the east before sunrise. Jupitor rises at $1 \mathrm{~h} 00 \mathrm{~m}, 0 \mathrm{~h} 10 \mathrm{~m}$ and $23 \mathrm{~h} 05 \mathrm{~m}$ at the beginning, middle and end of the month, respectively. It is in Aries, its stellar magnitude is $-\mathrm{I} \cdot 8$ and its distance from the Earth at the middle of the month is 500 million miles. Saturn rises at $22 \mathrm{~h} 50 \mathrm{~m}, 21 \mathrm{~h} 50 \mathrm{~m}$ and $20 \mathrm{~h} 50 \mathrm{~m}$ on July 1,15 and 31 , respectively. It is in Aquarius, its stellar magnitudo is +0.9 and its distance from the Earth on July 15 is 838 million miles. 'There are no occultations of stars brighter than magnitude 6 visible at Greonwich. The $\delta$ Aquarid meteors are active during July 15-August 10, with a muximum on July 29 , but they cannot be woll observed in latitudes so far north as Britain. The Earth is at apholion on July 5, when its distanco from the Sun is $\mathbf{9 4 . 6}$ million miles.

\section{Announcements}

Pror. K. Ziegler, of the Max Planck Institute, Mulheim, has been awarded the Swinburne Medal of the Plastics Institute in recognition of his distinguished contributions to the field of olefine polymerization.

Dr. M. W. Holdgate, of the Biological Unit. British Antarctic Survey, has been awarded the Dr. W. S. Bruce
Memorial Prize for 1964, for his work on the ecology of the islands of the Antarctic Seas. The Prize is awarded jointly by the Royal Scottish Geographical Society, the Royal Physical Society, and the Royal Society of Edinbu'gh.

Mr. D. M. Warrington, of the University of Otago, Dunedin, New Zealand, has been appointed by the Royal Society, under the terms of the scheme to commemorate the late Lord Rutherford of Nelson, to a Rutherford Scholarship for three years, to work at the Clarendon Laboratory, University of Oxford, in the field of the investigation of the properties of resonance radiation.

A Conference on "Air Pollution", arranged by the Council of Europe. will bo held in Strasbourg during June 24-July 1. Further information can be obtained from the Information Officer, National Society for Clean Air, Field House, Breams Buildings, London, E.C.4.

A THREE-DAY residential summer school entitled "Progress in the Chemistry and Technology of Pigments" will be held in the University of Leeds during July 14-17. Further information can be obtained from Dr. D. Patterson, Department of Colour Chemistry and Dyoing, University of Leeds.

THE summer biological symposium of the University of Michigan on "Problems of Capillary Permeability in Health and Disease" will be held in the University during July 13-15. Further information can be obtained from the Symposium Co-ordinator, Department of Anatomy, University of Michigan, Ann Arbor.

A study week on "Plasmas in Space and in the Stars", arrarged jointly by the Departments of Astronomy and Radio Astronomy of the University of Manchester, will be held in the University during July 20-24. Further information can be obtained from Dr. F. D. Kahn, Astronomy Department, University of Manchester.

AN international symposium on "Organic Photochemistry", sponsored by the International Union of Pure and Applied Chemistry, will be held in Strasbourg during July 16-24. Further information can be obtained from Dr. G. S. Hammond, Gates and Crellin Laboratories of Chemistry, California Institute of Technology, Pasadena, California.

A SUMMER sehool, under the sponsorship of NATO, will be held at the University of Ghent during July 27Ar:gust 7. The subject of the school will be lasers, with special reference to non-linear phenomena. Further information can be obtained from Prof. W. Dekeyser, Laboratorium voor Kristallografie on Studie van Vaste Stoffen, Rozier 6, Ghent.

A coUnse of lectures on "Engineering Information Retrieval", arranged by the Institution of Chemical Engineering, will be delivered by Mr. B. E. Holm (E.I. Du Pont de Nemours and Co.) at the Imperial College of Science and Technology during June 29-July 2. Further information can be obtained from the Institution of Chemical Engineers, 16 Belgrave Square, London, S.W.1.

THE fourth International Congress of Photobiology, organized by the British Photobiology Group under the auspices of the Comité International de Photobiologie, will be held in Oxford during July 26-30. The programme will include discussions on the following topics: basic photochemistry in relation to photobiology; photochemistry of nucleic acids and its biological implications; human colour vision; photoreception; photoenvironment; energy conversion and the photosynthetic unit; microirradiation of cells. Further information can be obtained from the Congress Office, Blandford Site, Whiteknight Park, Reading. 